\title{
Türkiye Bisküvi, Çikolatalı ve Şekerli Mamuller Sektörü: Firma Yoğunlaşma Analizi
}

\author{
Kübra ÖNDER ${ }^{1}$
}

\begin{abstract}
$\ddot{O} z$
Yoğunlaşma kavramı, ürün piyasasında alıcı ve satıcıların sayı ve büyüklük bakımından dă̆llımı olarak ifade edilmektedir. Yoğunlaşma ile sektördeki firma sayısı ve rekabet arasında ters yönlü bir ilişki vardır; yoğunlaşma arttıkça piyasadaki firma sayısı azalmakta ve buna bağll olarak rekabet şansı da azalmaktadır. Piyasadaki yoğunlaşma düzeyini ölçmek için kullanılan birçok yöntem bulunmaktadır. Çalışmada N-firma Yoğunlaşma Oranlarl (CR-4 ve CR-8), Herfindahl-Hirschman, Entropi ve Rosenbluth Indeksleri yardımı ile Türkiye bisküvi, çikolatal ve şekerli mamuller sektöründeki yoğunlaşma düzeyi 19972014 dönemi verileri kullanılarak analiz edilmiştir. Yapılan analiz sonucunda; CR-4 ve CR-8 yoğunlaşma oranlarına göre sektörde yüksek düzeyde yoğunlaşmanın olduğu; Herfindahl-Hirschman, Entropi ve Rosenbluth indeksi analizi sonuçlarına göre ise sektörün monopolcü rekabet ile oligopol arasında yer aldığı görülmektedir.
\end{abstract}

Anahtar Kelimeler: Bisküvi, Çikolatalı ve Şekerli Mamuller Sektörü, Piyasa Yapısı, Sektörel Yoğunlaşma

JEL Sinıflandırma Kodları: D22, D40, Q13, L10

\section{Turkish Biscuits, Chocolate and Sugar Products Sector: Firm Concentration Analysis}

\begin{abstract}
The concept of concentration refers to the distribution of customers and sellers in terms of number and size in the goods market. There is a reverse relationship between concentration, and the number of firms and the level of competition; the lower the number of firms, the more concentration ratio and the lower the level of competition. There are various methods to measure concentration level in a certain market. In the study, concentration ratio in Turkish biscuit, chocolate and sugar products sector is analysed by using time series data for the period 1997-2014 through N-Firm Concentration Rates (CR4 and CR-8), Herfindahl-Hirschman, Entropy, Rosenbluth Indices. As a result of the analysis, high level of concentration is determined according to CR-4 and CR-8 concentration ratios in the sector, while according to the Herfindahl-Hirschman, Entropy and Rosenbluth Indices the results reveal that the sector has a structure between monopolistic competition and oligopoly.
\end{abstract}

Keywords: Biscuits, Chocolate and Sugar Products, Market Structure, Sectoral Concentratio

JEL Classification Codes: D22, D40, Q13, L10

${ }^{1}$ Yrd.Doç.Dr., Mehmet Akif Ersoy Üniversitesi, İktisadi ve İdari Bilimler Fakültesi, İktisat Bölümü, konder@mehmetakif.edu.tr 


\section{K. ÖNDER.}

\section{GİRIŞ}

Dünyada mal ve hizmet piyasaları incelendiğinde, farklı piyasa türlerinin özelliklerini taşıyan piyasa yapıları ile karşılaşılmaktadır. Bazı piyasalarda üst düzeyde rekabet yaşanırken, bazı piyasalar ise tam rekabetten yoksundur. Günümüzde firmalar piyasa paylarını, karlarını artırmak ve maliyetlerini düşürmek vb. amaçlarla çeşitli faaliyetlerde bulunarak piyasayı rekabet ortamından uzaklaştırıp piyasa başarısızlıklarından biri olan aksak rekabet piyasalarının oluşmasına neden olmaktadır. $\mathrm{Bu}$ amaç doğrultusunda firmalar mal farklılaştırmasına gitmek, ölçek ekonomilerini sağlamak, firmalar arası anlaşmalar yapmak ve çeşitli pazarlama teknikleri gibi yöntemleri kullanmaktadırlar. Dolayısıyla piyasalar hakkında öngörüde bulunmak ve üreticilerin hangi piyasa yapısına sahip olduklarını görebilmek zorlaşmaktadır. Piyasa yapısını belirlemek için birçok yöntem kullanılmaktadır. Bu yöntemlerden en çok kullanılanlar YapıDavranış-Performans (Structure-Conduct-Performance SCP) yaklaşımı kapsamında yer alan N-firma Yoğunlaşma Oranı ve Herfindahl-Hirschman İndeksi iken (Polat, 2007: 98) son dönemde Entropi, Rosenbluth, Kapsamlı Yoğunlaşma gibi diğer indekslerin de kullanıldığı görülmektedir.

Piyasa yoğunlaşma indeksleri, piyasa gücünün hesaplanmasında yararlı ve pratik göstergeler sağlayarak piyasanın ne kadar rekabetçi olduğuna ilişkin ipuçları vermektedir. Başka verilerle birlikte ele alındığında bu indeksler firmanın piyasadaki gücünün belirlenmesinde çok daha etkin sonuçlar sunmaktadır. Piyasada faaliyet gösteren firma sayısı arttıkça ve firmalar verimlilik ve maliyet açısından birbirine yaklaştıkça yoğunlaşma azalmakta, piyasadaki rekabet artmakta ve firmaların piyasa değişkenlerini etkileme güçleri azalmaktadır (Kaynak ve Ari, 2011: 40-41). Yüksek yoğunlaşma oranları, piyasa başarısızlıklarından biri olan eksik rekabet şartlarının varlığı konusunda önemli bir gösterge olduğu için piyasa yoğunlaşma oranlarının bilinmesi önemlidir.

Türkiye'de üretimine 1924 y1lında bisküvi üretimi ile başlayan bisküvi, çikolatalı ve şekerli mamuller sektörü bugün, çoğunluğu modern teknoloji ile 
donatılmış 40'ı aşkın fabrika ile faaliyet göstererek y1llık yaklaşık 1.700 bin ton düzeyindeki üretim kapasitesi ile özellikle Orta Anadolu, Marmara, ve Güney Doğu Anadolu bölgelerinde yoğunlaşmıştır (www.tuik.gov.tr, 26.03.2016).

Nüfus artışı, genç nüfusun tüketim kalıbındaki değişim ve ihracata yönelik teşvik uygulamaları ile birlikte sektör ekonomide ilgi odağı olmuş ve sektöre yönelik yatırımlar özellikle de ihracata yönelik yatırımlar artırmıştır. Bu nedenle çalışmada; tahıla dayalı ürünler içinde en yüksek katma değer yaratan, 2015 Ekim ayı itibariyle \%10,5 işsizliğin yaşandığı, emek yoğun üretim kalıbı ile iş yaratma fırsatına sahip olan ve Türkiye Kalkınma Bankası tarafından oluşturulan genel performans sıralamasında 110 sektör içinde 22 'nci sırada yer alarak gelecek vaat eden sektörlerden biri olan bisküvi, çikolatalı ve şekerli mamuller sektörü incelenmiştir.

Tahıla dayalı ürünler içinde en fazla katma değer yaratan bisküvi sektörü ile çikolatalı ve şekerli mamuller sektörünün piyasa yapısını belirlemeyi amaçlayan bu çalışmanın ilk bölümünde, Türkiye'nin bisküvi, çikolata ve şekerli mamuller sektörü incelenmiştir. İkinci bölümde, çeşitli sektörlerde piyasa yapısını inceleyen çalışmalara ait literatüre yer verilmiş; üçüncü bölümde, yoğunlaşma ve yoğunlaşma üzerinde etkili olan unsurlara değinilmiştir. Dördüncü bölümde yoğunlaşma indekslerinden bahsedilmiş ve takip eden beşinci bölümde ise bisküvi, çikolata ve şekerli mamuller sektörü'nün piyasa yapısı analiz edilmiştir. Çalışmanın son bölümünde ise sektörün piyasa yapısı ile ilgili değerlendirme yapılmıştır.

\section{TÜRKIYYE'DE BİSKÜVİ, ÇİKOLATALI VE ŞEKERLİ MAMULLER SEKTÖRÜ}

Beslenme açısından önemli bir yere sahip olan bisküvi, 19'uncu yüzyıla kadar lüks bir tüketim maddesi olarak kabul edilirken, modern dünyada hayat tarzlarının değişmesi ile artık herkes tarafından kolaylıkla tüketilebilen bir gıda maddesi olmuştur (http://www.ito.org.tr, 31.03.2016). İş hayat1 ve uzun seyahatler nedeniyle aile yemeklerinin hazırlanması için geçen zaman ve enerji kısıntından dolayı işlenmiş yiyecekler, özellikle bisküvi, kurabiye, kek vb. gibi "atıştırılan" 


\section{K. ÖNDER.}

yiyeceklerin tüketiminde yaşanan olumlu gelişmeler bisküvi üretimini de artırmıştır.

Bisküvi ve gofret üretimi, tarıma dayalı sanayinin ağırlıkta olduğu Orta Anadolu Bölgesinde, özellikle de Karaman ilinde küçük imalathanelerde geleneksel üretim yöntemleri ile başlamıştır. Zaman içerisinde bisküvi ve gofret üretimine çikolata, çiklet, kek, şekerleme de dâhil olmuş ve bu sektör başta Karaman olmak üzere bisküvide Konya, Eskişehir ve Ankara; çikolata üretiminde, Konya, Gaziantep, Bursa, Adana, Eskişehir, İzmir ve Denizli; şekerli mamuller üretiminde ise İstanbul, Ankara, İzmir, Afyon, Konya, Kayseri, Kocaeli, Bursa, Balıkesir, Antalya, Denizli, Adana, Mersin ve Samsun gibi illerde yoğunlaşarak dev bir iş koluna dönüştüğü görülmektedir (www.kalkinma.com.tr, 26.03.2016). Günümüzde modern teknolojiyle donatılan sektör, hem ürün yelpazesini genişletmiş hem de uygulanan ihracat teşviklerinin pozitif bir yansıması olarak firma sayısını ve üretim kapasitesini arttırarak dünyanın birçok ülkesine binlerce ton ürün gönderen bir sanayiye dönüşmüştür. 1989-90 yıllarında fabrikaların üretimi yaklaş1k 150-200 tonken bu oran piyasaya girişte yaşanan kolaylık, uygulanan yatırım teşvikleri ve hızla gelişen ihracat olanakları, kentleşme ve genç nüfus oranında görülen artışlar ile farklı ve yeni tatlara açık olan genç nüfus eğiliminin bir sonucu olarak bisküvi üretimi 724 bin tona; çikolata üretimi 554 bin tona ve şekerli mamuller üretimi ise 370 bin tona yükselmiştir (Tablo 1) (www.ekonomi.gov.tr, 2013; www.ankaratb.org.tr, 2008: 3-4).

Tablo 1. Türkiye’nin Bisküvi, Çikolatalı ve Şekerli Mamuller Üretimi (Bin Ton)

\begin{tabular}{|c|c|c|c|c|c|c|c|c|c|}
\hline Ürünler & 2005 & 2006 & 2007 & 2008 & 2009 & 2010 & 2011 & 2012 & 2013 \\
\hline $\begin{array}{c}\text { Bisküvi } \\
\text { (Tatlı Bisküvi Dâhil) }\end{array}$ & 442 & 464 & 526 & 670 & 614 & 602 & 653 & 669 & 724 \\
\hline $\begin{array}{c}\text { Çikolata (Beyaz } \\
\text { Çikolata Hariç) }\end{array}$ & 248 & 269 & 288 & 363 & 363 & 409 & 453 & 495 & 554 \\
\hline $\begin{array}{c}\text { Şekerli Mamuller } \\
\text { Sekn }\end{array}$ & 208 & 217 & 244 & 239 & 229 & 276 & 305 & 370 \\
\hline
\end{tabular}

Kaynak: TÜIK, Sanayi Ürünleri Yıllık Üretim ve Satış İstatistikleri, 2005 - 2013, http://www.tuik.gov.tr/PreTablo.do?alt_id=1066, (09.01.2016). 
Dokuz Eylül Üniversitesi Iktisadi ve İdari Bilimler Fakültesi Dergisi Cilt:31, Sayl:2, Yll:2016, ss. 179-208

Tablo 1'de de görüldüğü gibi, Türkiye'de bisküvi (gofret dâhil), çikolatalı ve şekerli mamuller üretimi yıllar itibari ile artış göstermesine rağmen üretilen bu ürünlerin raf ömürlerinin kısa olması ve hacimli oluşları nedeni ile çok büyük kapasiteli depolara ihtiyaç duyulduğu için stoklama imkanları sınırlı tutulmakta ve söz konusu ürünlerin üretim miktarı talep ve satış durumuna göre belirlenmektedir (Sertakan, 2006: 4). Dolayısıyla, tahıla dayalı ürünler içinde en fazla katma değer yarattığı kabul edilen sektör, yatırımların özellikle ihracata yönelik yatırımların odağ1 olmuştur. 1994-1995'li yıllarda Sovyet Sosyalist Cumhuriyetler Birliği (SSCB)'nin dağılmasıyla birlikte kurulan yeni ülkeler sektör için önemli bir pazar konumuna gelmiştir. Son yıllarda özellikle, Eski Doğu Bloku ülkelerinin büyük miktarda ürün talebi de üretim hızını katlayarak artırmıştır (Tablo 2).

Tablo 2. Türkiye'nin Bisküvi, Çikolata ve Şekerli Mamuller İhracatı (Miktar, ton; Değer, bin dolar)

\begin{tabular}{|c|c|c|c|c|c|c|c|c|}
\hline Ürün & \multicolumn{2}{|c|}{$\begin{array}{c}\text { Tatlı Bisküvi } \\
\text { (Gofret Dahil) }\end{array}$} & \multicolumn{2}{|c|}{ Bisküvi } & \multicolumn{2}{|c|}{$\begin{array}{c}\text { Çikolatalı } \\
\text { Mamuller }\end{array}$} & \multicolumn{2}{c|}{$\begin{array}{c}\text { Sekerli Mamuller } \\
\text { Beyaz Çikolata } \\
\text { Dahil) }\end{array}$} \\
\hline Yıl & Miktar & Değer & Miktar & Değer & Miktar & Değer & Miktar & Değer \\
\hline 2002 & 70.150 & 46.477 & 3.456 & 31.649 & 41.639 & 79.104 & 46.131 & 98.831 \\
\hline 2003 & 95.034 & 70.646 & 4.567 & 49.931 & 61.698 & 129.795 & 55.645 & 121.783 \\
\hline 2004 & 111.765 & 82.088 & 3.939 & 50.638 & 72.059 & 161.281 & 67.654 & 157.157 \\
\hline 2005 & 110.111 & 85.689 & 4.245 & 58.046 & 81.489 & 191.844 & 74.750 & 177.343 \\
\hline 2006 & 115.621 & 90.527 & 4.358 & 63.734 & 105.445 & 241.714 & 85.672 & 193.704 \\
\hline 2007 & 136.062 & 121.033 & 5.266 & 82.185 & 136.135 & 324.642 & 94.826 & 241.377 \\
\hline 2008 & 124.936 & 149.909 & 5.473 & 105.592 & 128.959 & 355.512 & 102.196 & 287.867 \\
\hline 2009 & 119.254 & 138.918 & 5.098 & 100.092 & 122.826 & 328.654 & 94.288 & 256.409 \\
\hline 2010 & 145.241 & 171.130 & 5.150 & 98.536 & 137.220 & 364.472 & 102.992 & 279.009 \\
\hline 2011 & 180.458 & 256.445 & 3.522 & 66.185 & 149.398 & 433.839 & 120.492 & 328.888 \\
\hline 2012 & 198.336 & 265.764 & 3.186 & 58.947 & 157.292 & 478.895 & 145.485 & 403.018 \\
\hline 2013 & 222.578 & 297.584 & 3.284 & 62.213 & 180.294 & 542.728 & 172.519 & 489.756 \\
\hline 2014 & 231.733 & 311.015 & 3.332 & 61.737 & 191.532 & 576.761 & 187.224 & 536.918 \\
\hline
\end{tabular}

Kaynak: TradeMap, http://www.trademap.org/Country_SelProductCountry_TS.aspx, (22.12.2015). 


\section{K. ÖNDER.}

Bisküvi, çikolata ve şekerli mamuller sektörüne ait ilk önemli ihracat 1980 yılında 2700 ton olarak gerçekleşmiştir. 1997 yılında Rusya ve Orta Asya Cumhuriyetlerini hedef pazar seçen Türkiye'nin ihracatı, 1998 yılında yaşanan küresel krize kadar önemli bir gelişme göstermiştir. Küresel ekonomik kriz yurt içi ve yurt dışı talebi olumsuz yönde etkilemiştir. Yine aynı dönemde özellikle bisküvi sektörünün önemli bir girdisi olan buğdaya Toprak Mahsulleri Ofisi (TMO)'nin dünya fiyatlarının üzerinde bir fiyat belirlemesinin sonucu olarak sektör maliyetlerinin artması, bu döneme ait üretim miktarının düşmesine neden olmuştur. Sektör bu durumdan kurtulabilmek için yeni pazar arayışına girmiş ve düşük kar marjı ile Afrika ve Balkan ülkeleri pazarından pay elde etmeye çalışmıştır. Türkiye'nin pazar payı elde etme çalışmaları sonuçsuz kalmamış ve sektöre ait ürün ihracatında hızlı bir artış izlenmiştir. Sektörde yaşanan bu artış 2008 finansal krizine kadar devam etmiştir. 2008 yılında sektörün ihracat miktarında bir düşüş yaşanmasına rağmen bu düşüş kriz sonrası süreçte miktar ve değer bakımından telafi edilmiştir (www.ekonomi.gov.tr, 2003). Bisküvi sektöründe ise 2008 yılına kadar ihracat artmış, sektörde yer alan diğer ürünlerin tersine takip eden yıllarda ise giderek azalmıştır.

Sektöre ait ürün ihracat1 ülke bazında incelediğinde; 2002-2014 döneminde ihraç edilen bazı ürünlerin ülke yelpazesinde ciddi bir değişim yaşandığ 1 görülmektedir (Tablo 3). 2002 y1lına kadar sektöre ait ürünlerin ihracatı yapılmayan Irak, 2003 yılından itibaren sektörün en önemli pazarı haline gelmiş ve 2014 yılı itibariyle çikolatalı ve şekerli mamuller ihracatının \%17,13’ü (190 milyon dolar), bisküvi ihracatının \%27'si (125 milyon dolar) bu ülkeye yapılmıştır. 2002 yılı itibariyle en büyük sektör ihracatçısı olan Suudi Arabistan ile ihracat ise dalgalı bir seyir izlemiştir. 2014 yılında yapılan 51 milyon dolarlık ihracat, Suudi Arabistan'ı çikolatalı ve şekerli mamuller ihracatında dördüncü sıraya, bisküvi ihracatında ise üçüncü sıraya geriletmiştir. İhracat yapılan ülkelerin geneline bakıldığında; ağırlıklı olarak Ortadoğu, Afrika, Orta Asya Cumhuriyeti ile bazı Avrupa Birliği ülkelerine yapıldığı görülmektedir. 
Dokuz Eylül Üniversitesi Iktisadi ve İdari Bilimler Fakültesi Dergisi Cilt:31, Sayl:2, Yll:2016, ss. 179-208

Türkiye bisküvi, çikolatalı ve şekerli mamuller tüketiminde çoğu dünya ülkesinin gerisinde yer almaktadır. Bu nedenle, Türkiye çikolatalı ve şekerli mamuller ihracatçısı özellikle de tatlı bisküvi ihracatçısı olarak bilinmektedir (http://www.kalkinma.com.tr, 01.04.2016). Ancak son dönemlerde sektör ithalatında küçümsenmeyecek oranlarda artış yaşanmıştır. 2002-2014 dönem verileri incelendiğinde; 2002 yılında 3,6 milyon dolar olan tatlı bisküvi ihracatı $\% 14,2$ artarak 25,2 milyon dolara yükselmiş, bisküvi ithalatı \%8 artarak 0,3 milyon dolara, çikolatalı mamuller ithalatı \% 10 artarak 16,9 milyon dolara ve şekerli mamuller ithalatı ise \%8 artarak 98 milyon dolara ulaşmıştır (Tablo 4).

Tablo 4. Türkiye'nin Bisküvi, Çikolata ve Şekerli Mamuller İthalatı (Miktar: ton; Değer: bin Dolar)

\begin{tabular}{|c|c|c|c|c|c|c|c|c|}
\hline Ürün & \multicolumn{2}{|c|}{$\begin{array}{c}\text { Tatlı Bisküvi } \\
\text { (Gofret Dahil) }\end{array}$} & \multicolumn{2}{|c|}{ Bisküvi } & \multicolumn{2}{c|}{$\begin{array}{c}\text { Çikolatalı } \\
\text { Mamuller }\end{array}$} & \multicolumn{2}{c|}{$\begin{array}{c}\text { Şekerli Mamuller } \\
\text { Beyaz Çikolata } \\
\text { Dahil) }\end{array}$} \\
\hline Y11 & Miktar & Değer & Miktar & Değer & Miktar & Değer & Miktar & Değer \\
\hline 2002 & 1.189 & 3.588 & 1.809 & 2.109 & 5.821 & 20.274 & 1.077 & 2.523 \\
\hline 2003 & 1.270 & 4.221 & 2.045 & 2.785 & 6.366 & 24.060 & 1.295 & 3.212 \\
\hline 2004 & 1.578 & 6.041 & 3.597 & 7.123 & 9.264 & 36.137 & 1.591 & 4.166 \\
\hline 2005 & 2.469 & 9.672 & 3.975 & 5.427 & 9.725 & 41.544 & 1.985 & 4.771 \\
\hline 2006 & 3.116 & 11.798 & 4.776 & 6.653 & 13.055 & 58.484 & 1.488 & 5.015 \\
\hline 2007 & 3.580 & 14.298 & 5.664 & 9.519 & 13.276 & 64.349 & 1.892 & 7.394 \\
\hline 2008 & 4.663 & 18.705 & 8.286 & 16.661 & 15.310 & 80.343 & 4.059 & 16.627 \\
\hline 2009 & 4.930 & 18.624 & 8.941 & 19.460 & 15.784 & 77.208 & 3.462 & 15.139 \\
\hline 2010 & 5.792 & 20.526 & 11.937 & 27.098 & 18.516 & 89.227 & 2.373 & 10.074 \\
\hline 2011 & 5.913 & 21.630 & 13.145 & 33.485 & 19.635 & 91.693 & 2.953 & 13.010 \\
\hline 2012 & 5.632 & 19.718 & 15.032 & 42.180 & 21.196 & 100.653 & 2.542 & 10.719 \\
\hline 2013 & 7.642 & 27.047 & 18.029 & 47.095 & 20.750 & 111.379 & 3.010 & 13.623 \\
\hline 2014 & 6.913 & 25.207 & 15.716 & 34.260 & 16.227 & 98.108 & 3.666 & 16.895 \\
\hline
\end{tabular}

Kaynak: TradeMap, http://www.trademap.org/Country_SelProductCountry_TS.aspx, (10.01.2016). 


\section{K. ÖNDER.}

Tablo 3. Ülkeler İtibariyle Türkiye'nin Bisküvi, Çikolatalı ve Şekerli Mamuller İhracatı (Değer, bin dolar)

\begin{tabular}{|c|c|c|c|c|c|c|c|c|c|}
\hline \multicolumn{9}{|c|}{ Bisküvi (Tatlı Bisküvi Dahil) } & \multicolumn{4}{|c|}{ Çikolatalı ve Sekerli Mamuller } \\
\hline Ülke & $\mathbf{2 0 1 1}$ & $\mathbf{2 0 1 2}$ & $\mathbf{2 0 1 3}$ & $\mathbf{2 0 1 4}$ & Ülke & $\mathbf{2 0 1 1}$ & $\mathbf{2 0 1 2}$ & $\mathbf{2 0 1 3}$ & $\mathbf{2 0 1 4}$ \\
\hline Irak & 72.457 & 78.160 & 89.015 & 80.894 & Irak & 128.673 & 149.379 & 188.455 & 190.812 \\
\hline Yemen & 26.683 & 20.674 & 24.573 & 32.074 & Cezayir & 49.232 & 37.144 & 42.716 & 42.291 \\
\hline Suudi Arabistan & 19.367 & 18.959 & 17.247 & 21.572 & Birleşik Arap Emirlikleri & 27.324 & 24.460 & 22.944 & 27.378 \\
\hline Almanya & 13.045 & 10.952 & 11.786 & 11.548 & Suudi Arabistan & 26.791 & 30.835 & 36.715 & 51.259 \\
\hline Cezayir & 11.928 & 12.048 & 11.521 & 11.363 & Romanya & 10.277 & 9.073 & 8.341 & 6.036 \\
\hline Azerbaycan & 11.384 & 12.590 & 16.542 & 18.058 & Libya & 23.721 & 39.690 & 42.257 & 34.766 \\
\hline Albania & 8.766 & 7.178 & 8.348 & 8.728 & İran & 23.051 & 19.364 & 21.332 & 33.360 \\
\hline Filistin & 8.320 & 7.567 & 8.343 & 9.439 & İsrail & 21.833 & 23.526 & 34.179 & 32.696 \\
\hline İsrail & 8.285 & 9.718 & 10.400 & 5.574 & Azerbaycan & 24.316 & 25.839 & 37.131 & 35.671 \\
\hline Libya & 7.873 & 11.643 & 8.912 & 7.088 & Tacikistan & 15.758 & 15.519 & 11.816 & 9.929 \\
\hline Senegal & 7.761 & 3.734 & 2.782 & 2.730 & Türkmenistan & 14.527 & 13.151 & 12.115 & 11.677 \\
\hline Romanya & 7.645 & 7.918 & 11.602 & 10.747 & Yemen & 12.950 & 17.319 & 19.621 & 22.744 \\
\hline ABD & 7.645 & 7.918 & 11.602 & 10.747 & Bulgaristan & 12.484 & 12.728 & 14.074 & 13.582 \\
\hline Bulgaristan & 6.656 & 4.978 & 5.745 & 4.747 & Kazakistan & 13.270 & 13.581 & 17.670 & 17.707 \\
\hline
\end{tabular}


Dokuz Eylül Üniversitesi İktisadi ve İdari Bilimler Fakültesi Dergisi Cilt:31, Sayl:2, Yll:2016, ss. 179-208

\begin{tabular}{|c|c|c|c|c|c|c|c|c|c|}
\hline \multicolumn{5}{|c|}{ Bisküvi (Tatı Bisküvi Dahil) } & \multicolumn{5}{|c|}{ Çikolatalı ve Şekerli Mamuller } \\
\hline Ülke & 2011 & 2012 & 2013 & 2014 & Ülke & 2011 & 2012 & 2013 & 2014 \\
\hline Irak & 72.457 & 78.160 & 89.015 & 80.894 & Irak & 128.673 & 149.379 & 188.455 & 190.812 \\
\hline Yemen & 26.683 & 20.674 & 24.573 & 32.074 & Cezayir & 49.232 & 37.144 & 42.716 & 42.291 \\
\hline Suudi Arabistan & 19.367 & 18.959 & 17.247 & 21.572 & Birleşik Arap Emirlikleri & 27.324 & 24.460 & 22.944 & 27.378 \\
\hline Almanya & 13.045 & 10.952 & 11.786 & 11.548 & Suudi Arabistan & 26.791 & 30.835 & 36.715 & 51.259 \\
\hline Diğerleri & 104.815 & 110.674 & 121.379 & 137.443 & Diğerleri & 358.520 & 450.305 & 523.118 & 583.771 \\
\hline Toplam & 322.630 & 324.711 & 359.797 & 372.752 & Toplam & 762.727 & 881.913 & 1.032 .484 & 1.113 .679 \\
\hline
\end{tabular}

Kaynak:TradeMap,http://www.trademap.org/Country_SelProductCountry_TS.aspx,(22.12.2015). 


\section{K. ÖNDER.}

Sektör ithalatının ülke ağırlığına bakıldığında ağırlıklı olarak AB ülkelerine yapıldığı ve en fazla ithalat yapılan ilk dört ülkenin bisküvi sektöründe; Belçika, Almanya, Hollanda ve Polonya olduğu; çikolatalı ve şekerli mamuller sektöründe ise Almanya, Hollanda, Belçika ve İtalya'nın olduğu görülmektedir. 2014 yılı için bu dört ülkenin toplam bisküvi sektörü ithalatı içindeki payı $\% 75$, çikolatalı ve şekerli mamuller sektör ithalatı içindeki payı ise \%65'dir. Yıılardır çikolatalı ve şekerli mamuller sektörünün lideri olan Almanya, Bisküvi sektöründe 11.664 bin dolarlık ithalatıyla yerini 15.507 bin dolarlık ithalat yapılan Belçika'ya kaptırmıştır (Tablo 5).

\section{LITERATÜR TARAMASI}

Literatürde yoğunlaşma oranının belirlenmesi konusunda çeşitli sektörleri ele alan yerli ve yabancı birçok çalışma bulunmaktadır. Söz konusu çalışmaların bir kısmının tek denklem, eşanlı denklem sistemi ve panel veri yöntemlerini kullanarak; diğer bir kısmının ise N firma yoğunlaşma oranı, HerfindahlHirschman indeksi gibi nispi ve kapsamlı yoğunlaşma indekslerinden yararlanarak piyasa yoğunlaşma derecesini belirleyip piyasa yapısını değerlendirdiği görülmektedir. Ancak araştırma kapsamında yapılan ulusal ve uluslararası yazında, Bisküvi, Çikolatalı ve Şekerli Mamuller Sektörü'nün bir bütün olarak incelenmediği, piyasa yoğunlaşması açısından analiz edilmediği ve ulusal yazında, sektöre yönelik çalışmaların nicel araştırma yöntemi kullanılarak; marka bağımlılığının veya tüketici eğilimlerinin incelendiği görülmektedir (Özel, 2006; Ondoğan, 2008; Ünal, Deniz ve Can, 2008).

Çeşitli sektörler için piyasa yoğunlaşması konusunu inceleyen yerli ve yabancı çalışmalara Tablo 6'da yer verilmiştir. 
Dokuz Eylül Üniversitesi İktisadi ve İdari Bilimler Fakültesi Dergisi Cilt:31, Sayl:2, Yll:2016, ss. 179-208

Tablo 5. Ülkeler İtibariyle Türkiye’nin Bisküvi, Çikolatalı ve Şekerli Mamuller İthalatı (Değer, bin dolar)

\begin{tabular}{|c|c|c|c|c|c|c|c|c|c|}
\hline \multicolumn{4}{|c}{ Bisküvi } & \multicolumn{5}{c|}{ Çikolatalı ve Şekerli Mamuller } \\
\hline Ülke & $\mathbf{2 0 1 1}$ & $\mathbf{2 0 1 2}$ & $\mathbf{2 0 1 3}$ & $\mathbf{2 0 1 4}$ & Ülke & $\mathbf{2 0 1 1}$ & $\mathbf{2 0 1 2}$ & $\mathbf{2 0 1 3}$ & $\mathbf{2 0 1 4}$ \\
\hline Belçika & 11.191 & 14.777 & 20.843 & 15.507 & Almanya & 13.177 & 19.304 & 29.359 & 34.741 \\
\hline Almanya & 15.579 & 21.647 & 17.878 & 11.664 & Hollanda & 10.563 & 13.782 & 16.095 & 19.926 \\
\hline Hollanda & 5.561 & 5.234 & 9.654 & 7.921 & Belçika & 9.316 & 10.940 & 14.564 & 10.607 \\
\hline Polonya & 9.189 & 6.263 & 6.997 & 7.076 & İtalya & 5.151 & 21.120 & 19.842 & 8.981 \\
\hline İtalya & 5.397 & 5.586 & 6.712 & 5.989 & İsviçre & 4.657 & 4.475 & 8.570 & 7.850 \\
\hline Bulgaristan & 2.701 & 2.953 & 3.288 & 2.871 & ABD & 2.709 & 4.204 & 6.203 & 7.311 \\
\hline İsviçre & 990 & 814 & 1.171 & 741 & Polonya & 34.755 & 25.689 & 14.056 & 7.025 \\
\hline Fransa & 857 & 369 & 403 & 762 & Bulgaristan & 5.200 & 1.310 & 1.223 & 1.510 \\
\hline Birleşik Krallık & 751 & 920 & 894 & 730 & Slovenya & 7.641 & 1.341 & 605 & 869 \\
\hline Diğerleri & 2.899 & 3.335 & 6.302 & 6.206 & Diğerleri & 11.534 & 9.207 & 14.485 & 16.183 \\
\hline Toplam & 55.115 & 61.898 & 74.142 & 59.467 & Toplam & 104.703 & 111.372 & 125.002 & 115.003 \\
\hline
\end{tabular}

Kaynak: TradeMap, http://www.trademap.org/Country_SelProductCountry_TS.aspx, (10.01.2016). 


\section{K. ÖNDER.}

Tablo 6. Yoğunlaşmanın Analiz Edildiği Çeşitli Ampirik Çalışmalar

\begin{tabular}{|c|c|c|}
\hline Yazar & Kapsam & Yöntem \\
\hline $\begin{array}{l}\text { Donowitz, } \\
\text { Hubbard ve } \\
\text { Petersen (1987) }\end{array}$ & $\begin{array}{l}284 \text { imalat sanayi sektörünün 1958-1981 dönemine ait verilerini kullanarak fiyat-maliyet marjı } \\
\text { ile yoğunlaşma arasındaki ilişkiyi analiz etmiştir. }\end{array}$ & $\begin{array}{l}\text { Çoklu Regresyon } \\
\text { analizi }\end{array}$ \\
\hline Erlat (1991) & $\begin{array}{l}\text { 1970-1990 dönemi verileri kullanılarak Türkiye imalat sanayi (kimya, dokuma-giyim, cam- } \\
\text { seramik, demir-çelik ve taşıt araçları) alt sektörleri için ihracat ve yoğunlaşma arasındaki } \\
\text { ilişkiyi belirlemiştir. }\end{array}$ & $\begin{array}{l}\text { Hirschman- } \\
\text { Herfindahl (HH) } \\
\text { İndeksi, } \\
\text { Rosenbluth } \\
\text { indeksi (RI) ve } \\
\text { Entropi İndeksi }\end{array}$ \\
\hline Denizer (1999) & $\begin{array}{l}\text { Türk bankacılık sistemindeki yabancı girişimcilerin yoğunlaşma düzeyini 1980-1997 dönem } \\
\text { verileri kullanılarak analiz edilmiştir. Yurtiçi bankacılık sisteminde yaşanan rekabet ortamının } \\
\text { bankacılık sistemi içindeki yabancı girişimcilik yoğunlaşma düzeyini azalttığını ileri } \\
\text { sürmüştür. }\end{array}$ & $\begin{array}{l}\text { Regresyon } \\
\text { analizi }\end{array}$ \\
\hline $\begin{array}{ll}\text { Çil } & \text { Yavuz } \\
(2000) & \\
\end{array}$ & $\begin{array}{l}\text { Türkiye'de uygulamaya konulan dış ticaret politikalarının ihracat ve ithalata etkisi } 1980 \text { öncesi } \\
\text { ve sonrası dönem için incelenmiştir. }\end{array}$ & $\begin{array}{l}\text { Gini-HH } \\
\text { yoğunlaşma ind.. }\end{array}$ \\
\hline $\begin{array}{l}\text { Aktaş ve } \\
\text { Yurdakul 2001) }\end{array}$ & $\begin{array}{l}\text { 1985-1997 y1lları arası Türkiye ve Dünya'daki un sanayi sektörü yoğunlaşma açısından } \\
\text { incelenmiş ve çok düşük oranda da olsa sektörün yoğunlaştığı tespit edilmiştir. }\end{array}$ & $\begin{array}{l}\mathrm{HH}, \quad \mathrm{N} \text { firma } \\
\text { yoğunlaşma ind. }\end{array}$ \\
\hline $\begin{array}{l}\text { Kösekahyaoğlu } \\
\text { (2007) }\end{array}$ & $\begin{array}{l}\text { 1980-2015 dönem verileri kullanılarak Türkiye'nin diş ticaretinde ürün ve ülke yoğunlaşma } \\
\text { düzeyi incelenmiş ve ürün çeşitlenmesi açısından Türkiye'nin dış ticaretinde olumlu sonuç elde } \\
\text { edilmiştir. }\end{array}$ & $\begin{array}{l}\text { Gini-HH } \\
\text { yoğunlaşma } \\
\text { indeksi }\end{array}$ \\
\hline Polat (2007) & $\begin{array}{l}2001-2005 \text { dönem verilerini kullanarak Türkiye çimento sektörünün piyasa yapısını } \\
\text { belirlemiştir. CR firma yoğunlaşma analizine göre firma yapısı monopolcü rekabet ile oligopol } \\
\text { piyasası sınırında yer alırken HH indeksine göre daha rekabetçi bir yapının varlığ } \\
\text { belirlenmiştir. }\end{array}$ & $\begin{array}{l}\mathrm{N} \text {-firma } \\
\text { yoğunlaşma oranı } \\
\text { ve } \mathrm{HH} \text { indeksi }\end{array}$ \\
\hline
\end{tabular}


Dokuz Eylül Üniversitesi İktisadi ve İdari Bilimler Fakültesi Dergisi Cilt:31, Sayl:2, Yll:2016, ss. 179-208

\begin{tabular}{|c|c|c|}
\hline Yazar & Kapsam & Yöntem \\
\hline Akal (2008) & $\begin{array}{l}\text { 1980-2005 verileri kullanılarak, Türkiye'nin Ortadoğu sınır ülkeleri ile olan dış ticaretindeki } \\
\text { yoğunlaşma düzeyi fasıl bazında analiz edilmiş ve yoğunlaşmanın tarımsal fasıldan sanayi } \\
\text { fasıllarına doğru kaydığı sonucuna ulaşılmışı. }\end{array}$ & Yapısal Analiz \\
\hline $\begin{array}{l}\text { Durukan ve } \\
\text { Hamurcu } \\
(2009)\end{array}$ & $\begin{array}{l}\text { Türkiye ve Kazakistan, Kırgızistan, Türkmenistan, Tacikistan ve Özbekistan'ın mobil iletişim } \\
\text { piyasalarının yoğunlaşma oranı ve piyasa yapısı 2002-2007 dönemi için analiz edilmiş ve } \\
\text { Türkiye, Kazakistan, Kırgızistan ve Türkmenistan'ın rekabetçi olmayan, oligopol bir piyasa } \\
\text { yapısına Tacikistan ve Özbekistan'ın ise orta derecede yoğunlaşmış bir oligopol yapısına sahip } \\
\text { olduğu sonucuna ulaşılmıştır. }\end{array}$ & $\begin{array}{l}\text { N-firma } \\
\text { yoğunlaşma oranı } \\
\text { ve HH indeksi }\end{array}$ \\
\hline $\begin{array}{l}\text { Küçükkiremitçi, } \\
\text { Karaca ve } \\
\text { Eşiyok (2010) }\end{array}$ & $\begin{array}{l}2007 \text { yılı verilerini kullanarak, Türkiye'nin ihracatında ilk beşte yer alan ülkelere yapılan } \\
\text { ihracatın sektörel profili ortaya konulmuş ve Türkiye'nin sektörel ve bölgesel yoğunlaşması } \\
\text { analiz edilmiştir. }\end{array}$ & $\begin{array}{l}\text { N-firma } \\
\text { yoğunlaşma oranı } \\
\text { ve HH indeksi }\end{array}$ \\
\hline $\begin{array}{l}\text { Kaynak ve Ari } \\
\text { (2011) }\end{array}$ & $\begin{array}{l}\text { 2003-2011 dönem verilerinin kullanıldı̆̆ı çalışmada Türk otomotiv sektörünün piyasa yapısı } \\
\text { yoğunlaşma oranı ile incelenmiş ve çalışma sonuçlarına göre, yerli binek araç piyasası ve yerli } \\
\text { hafif ticari araç piyasası için orta yoğunluklu monopolcü rekabetçi bir yapı, İthal binek ve ithal } \\
\text { hafif ticari araç piyasalarında ise düşük yoğunlaşma derecesi söz konusudur. }\end{array}$ & $\begin{array}{l}\text { N-firma } \\
\text { yoğunlaşma oranı } \\
\text { ve HH indeksi }\end{array}$ \\
\hline $\begin{array}{l}\text { Taru ve Lawal } \\
\text { (2011) }\end{array}$ & $\begin{array}{l}\text { Nijerya perakende ve toplan patates piyasasındaki yoğunlaşma düzeyi incelenmiş ve piyasanın } \\
\text { yüksek yoğunlaşmaya sahip oligopolist bir piyasa olduğuna tespit etmişlerdir. }\end{array}$ & $\begin{array}{l}\text { Gini Katsayıs1 ve } \\
\text { Lorenz Eğrisi }\end{array}$ \\
\hline $\begin{array}{l}\text { Nolan, Santos } \\
\text { ve Shi }(2012)\end{array}$ & $\begin{array}{l}\text { 2002-2009 dönem verileri ile Amerika mısır piyasasının yoğunlaşma düzeyi hesaplanmış ve } \\
\text { piyasa yoğunlaşması ile piyasa yenilikleri arasında pozitif bir ilişki bulunmuştur. }\end{array}$ & N yoğunlaşma \\
\hline $\begin{array}{l}\text { Pehlivanoğlu ve } \\
\text { Tekçe (2013) }\end{array}$ & $\begin{array}{l}\text { 1993-2011 dönemleri için İstanbul Ticaret Odası verilerini kullanarak Türkiye Elektrik } \\
\text { piyasasının yapısını analiz etmiştir. Analizde; piyasanın güçlü bir oligopolist duruma yakın } \\
\text { dolayısıyla da rekabetçi yapıdan uzak olduğu sonucuna ulaşılmıştır }\end{array}$ & $\begin{array}{l}\text { N-firma } \\
\text { yoğunlaşma oranı } \\
\text { ve HH indeksi }\end{array}$ \\
\hline Sung (2014) & $\begin{array}{l}\text { 1998-2014 dönemi için } 24 \text { OECD ülkesinin 1998-2014 dönem verileri kullanılarak mobil } \\
\text { iletişim piyasasındaki yoğunlaşma hesaplanmıştır. Ampirik sonuçlar mobil iletişim piyasasının } \\
\text { yoğunluk derecesinin yüksek olduğu desteklemektedir. }\end{array}$ & $\begin{array}{l}\text { Regresyon } \\
\text { analizi }\end{array}$ \\
\hline
\end{tabular}




\section{K. ÖNDER.}

\section{YOĞUNLAŞMA VE YOĞUNLAŞMA ÜZERİNDE ETKİLİ OLAN UNSURLAR}

Piyasa yapısı; sektördeki firma sayısı, ürün farklılaşması, giriş koşulları ve firmaların dikey olarak bütünleşme dereceleri incelenerek açıklanabilir. Piyasa yapısını belirlemek için en sık kullanılan ölçü, piyasa yoğunlaşmasıdır. Yoğunlaşma, alıcı ve satıcıların sayısı ve büyüklük dağılımı ile ilgili bir kavramdır. Yoğunlaşma derecesi, hem satıcıları hem de alıcıları yönetim ve performans yönünden etkilemesine rağmen alıcılar açısından yoğunlaşmayı ölçmenin oldukça zor olması, çalışmaların satıcılar üzerine yönelmesine neden olmaktadır.

Satıcılar açısından yoğunlaşma, toplam yoğunlaşma ve piyasa yoğunlaşması olmak üzere ikiye ayrılabilir. Toplam yoğunlaşma; toplam satışlardaki, varlıklardaki, istihdamdaki vb. değişkenlerdeki yoğunlaşmayı yansıtırken; piyasa yoğunlaşması, bazı endüstri veya piyasalardaki en büyük firmaların önemini yansitmaktadır.

Genel anlamda yoğunlaşma kavramı, bir piyasadaki alıcı ve satıcı firmaların sayısı ve büyüklük dağılımı ile ilgilidir. Ayrıca yoğunlaşma, belli bir bütüncüllük düzeyindeki ekonomik faaliyetin büyük bir oranının, bu faaliyete katılan birimler içindeki az sayıda birim tarafından kontrol altında tutulması (Bain, 1968: 78) veya endüstriyel yapı ve performansın ne derece tam rekabetçi, ne derece monopolcü şartlara yaklaştı̆̆ını belirten bir ölçüttür (Bailey ve Boyle, 1971; Marfels, 1975: 485). Başka bir ifade ile yoğunlaşma, bir piyasada hâkim firma sayısının bir göstergesidir. Buradan hareketle, az sayıda firmanın faaliyet gösterdiği bir piyasada, yoğunlaşmanın yüksek; çok sayıda firmanın faaliyette bulunduğu piyasada ise yoğunlaşmanın düşük olduğu söylenebilir. Ancak piyasadaki firma sayısının tek başına yoğunlaşmanın göstergesi olarak alınması, bazı eksiklikleri içinde barındırmaktadır. Piyasada faaliyet gösteren firma sayısı aynı olmasına rağmen firmaların büyüklükleri ya da piyasa payları birbirlerinden farklı olabilmektedir. Böyle bir durumda yoğunlaşma düzeyinin belirlenebilmesi için firma büyüklüklerinin ortaya konulması gerekmektedir. Piyasada faaliyet gösteren 
firmaların piyasa payları birbirine ne kadar yakın ise, o piyasada yoğunlaşmanın düşük olduğu, firma piyasa paylarının birbirinden farklılaştığı durumda ise yoğunlaşma oranının yüksek olduğu kabul edilir (Çermikli, 2014: 16-19).

Piyasa koşullarına göre farklı piyasa türlerinin görüldüğ̈ ticari hayatta, üretici davranışları piyasadan piyasaya farklılık göstermekte ve buna bağlı olarak da yoğunlaşmaya yol açan nedenler farklılaşmaktadır. Bu unsurların göreli ağırlığı bir endüstriden diğerine farklılık gösterebileceği gibi, zaman içinde de değişebilmektedir. Yoğunlaşmaya yol açan unsurların başında; ölçek ekonomileri, firma birleşmeleri, endüstriye giriş engelleri, ekonominin büyümesi, yeni teknolojinin uygulanması, reklamlar, ekonomi yönetimi ve hukuki düzenlemeler gibi birçok faktör sayılabilir (Hatırlı, 2014: 295).

Yoğunlaşmayı etkileyen faktörlerden biri ölçek ekonomileridir. Bir firmanın ortalama maliyeti üretim düzeyi arttıkça; artabilir, azalabilir veya sabit kalabilir. Eğer firmanın üretim hacmi arttıkça, ortalama maliyeti düşüyorsa (artıyorsa/değişmiyorsa) firmanın ölçek ekonomisinin olduğu veya ölçeğe göre artan getiriye (ölçeğe göre azalan getiriye/ ölçeğe göre sabit getiriye) sahip olduğu ifade edilir. Dolayısıyla, ölçek ekonomileri, üretim hacmi arttıkça uzun dönem ortalama maliyetin düşeceğini gösterir. Firmaların ölçek ekonomileri dolayısıyla sağlamış oldukları avantajlar arttıkça maliyetler düşecek, verimlilik artacak ve daha fazla üretebileceklerdir. Bunun sonucu olarak, bu firmaların piyasa paylarında artış yaşanacak ve firmaların piyasa yoğunlaşma derecesi artacaktır (Davut, 2002: 219). Bazen belirli bir piyasada faaliyette bulunan firmaların monopol gücü kazanmak ve karlarını artırmak amacıyla aralarında anlaşma yaparak piyasadaki rekabeti sınırlandırmaları da, yoğunlaşmayı etkileyen bir diğer unsur olarak ortaya çıkmaktadır (Utton, 1970: 31-32; Hannah ve Kay, 1977; Muller, 1976).

Yoğunlaşma derecesi üzerinde etkili olan bir başka faktör, endüstriye giriş engelleridir. Endüstriye giriş engelleri; endüstride mevcut firmaların, yeni firma girişini engelleyen minimum uzun dönem ortalama maliyetin üzerinde bir fiyat uygulamalarına olanak vermektedir ve bu durum piyasadaki mevcut firmaların lehine bir rekabet avantajı sağlamaktadır. Piyasaya giriş engellerinin firmalara 


\section{K. ÖNDER.}

sağladığ 1 bu şekildeki bir fayda, piyasada bulunan mevcut firmaların karlarının ve piyasa paylarının artmasına yol açmaktadır. $\mathrm{Bu}$ durumda giriş engeli, bir endüstrideki bir veya birkaç firmayı rekabette avantajlı duruma getirerek yoğunlaşma derecesinin artması ya da korunması üzerinde etkili olabilmektedir (Bain, 1968: 204).

Yoğunlaşma derecesi üzerinde etkili olan bir diğer unsur da ekonominin büyümesi ve piyasaların genişlemesidir. Ekonominin ve piyasaların sürekli büyümesi halinde, firmalar ekonomideki ve piyasadaki büyümeye aynı düzeyde ayak uyduramazlarsa bu durum, yeni firmaların piyasaya girmesine, dolayısıyla firmaların piyasa paylarının azalmasına ve yoğunlaşma derecesinin düşmesine neden olabilmektedir (Bain, 1968: 210; Low, 1970: 111).

Araştırma geliştirme (Ar-ge) faaliyetlerinde bulunma ve geliştirilen yeni teknoloji düzeyi, ürün çeşitliliğinde ve üretim miktarında bir artış sağlamakta, üretim maliyetlerinde düşüşe neden olmakta ya da veri girdi miktarı ile daha fazla çıktı elde etme imkanı sağlamakta ve teknolojiyi üretimde rekabet üstünlüğü sağlayan temel girdi konumuna taşımaktadır. Teknolojinin hızla gelişmesi ve uluslararası rekabet, firmaları diğer firmalara göre rekabet açısından daha üstün kılmaktadır. Bu durum, firmaların teknolojik yenilik yapma isteğini artırmakta ve yatırıma yönlendirmektedir. Ancak rekabetçi piyasadaki küçük firmalar yatırım yapabilecek kaynaklara sahip değildir. Piyasadaki güçlü üstün teknoloji, zaman içinde piyasadaki diğer küçük firmaların piyasa dışına çıkmasına ya da bu firmaların kapanmasına yol açmaktadır. $\mathrm{Bu}$ durum da, piyasa yoğunlaşma derecesinin yeni teknoloji kullanan firmaların lehine artmasına neden olmaktadır (Taymaz, www.rekabet.gov.tr, 26.03.2016).

Yoğunlaşmayı etkileyen unsurlar konusunda ileri sürülen bir başka görüş, temel girdinin kontrolü ve yasal engellerdir. Üretimde kullanılan temel girdinin tek bir firmanın veya hakim firmanın kontrolünde olması yoğunlaşmayı etkilerken; bir malın üretiminin patent ve telif hakları ile tek bir firmaya verilmesi de yoğunlaşmayı etkilemektedir (Hatırl1, 2014: 294). Ayrıca firmalara geniş alıcı 
kitlelerine ulaşma ve ürününü tanıtma şansı veren reklamlar ve hükümetlerin uyguladıkları etkin olmayan yönetim de piyasa yoğunlaşmasına neden olurken hukuki düzenlemeler, piyasa yoğunlaşma derecesinin azalmasında etkilidir.

\section{YOĞUNLAŞMA İNDEKSLERI}

Yönetim ve performansı etkileme yönünden alıcılar açısından yoğunlaşma derecesi, satıcılar açısından yoğunlaşma derecesi kadar önemli olmasına rağmen literatürde alıcılar açısından yoğunlaşma derecesi, bilgi toplama ve ölçmede yaşanan güçlükler gibi nedenler dolayısıyla çalışmalara fazla konu olmamıştır (Koch,1980: 172). Satıcılar açısından yoğunlaşma derecesi incelenirken, monopolleşme eğilimi ile bağlantı kurulmuş ve monopolün kaynak dağılımı ve refah üzerindeki olumsuz etkileri nedeniyle konu önem kazanmıştır. Ayrıca, yoğunlaşmayı ölçmenin daha kolay olması da konunun bir çok ampirik çalışmada konu edinilmesinde rol oynamıştır (Devine vd., 1974: 83).

Yoğunlaşma derecesinin ölçülmesi konusu üzerinde anlaşılmış temel bir yöntem bulunmamakla birlikte firma büyüklüğünü ölçmek için çeşitli yoğunlaşma ölçütleri bulunmaktadır. Bu ölçüler; mutlak ve göreli olmak üzere iki şekilde sınıflandırılmaktadır. Göreli yoğunlaşma ölçüleri, endüstrideki firmaların büyüklük dağılımındaki eşitsizliği yansıtmaya yönelikken; mutlak yoğunlaşma ölçüleri ise az sayıda büyük firmanın, endüstrideki satışları ne oranda kontrol altında tuttuğunu yansıtmaya yöneliktir (Utton, 1970: 35; Pickering, 1974: 5).

Uygulamada en sık kullanılan yoğunlaşma oranı, sektördeki en büyük $n$ firmanın piyasa paylarının toplamıdır ve cebirsel açıdan değerlendirildiğinde lineer bir ölçüm yapmaktadır (Shy, 1995: 172):

$$
\mathrm{C}_{\mathrm{k}}=\sum_{\mathrm{i}=1}^{\mathrm{n}} \mathrm{S}_{\mathrm{i}} \quad \mathrm{i}=1,2,3, \ldots \mathrm{n}
$$

Eşitlik 1'de yer alan $C_{k}$, "k" sayıdaki firmanın pazar paylarının yoğunlaşma oranını; $S_{i}$, “i”ninci firmanın endüstrideki pazar payını, "n” endüstrideki firma sayısını ifade etmektedir. n-firma yoğunlaşma oranı genelde 4 veya 8 firma için 


\section{K. ÖNDER.}

hesaplanmaktadır. $\mathrm{Bu}$ oran sıfır ile yüz arasında değerler almaktadır. n-firma yoğunlaşma oranı piyasanın en yüksek payına sahip ilk dört firma için hesaplandığında elde edilen değerdir; eğer 30'dan küçük ise düşük düzeyde yoğunlaşmadan, 30 ile 50 arasında ise orta düzey yoğunlaşmadan, 50 ile 70 arasında ise yüksek düzeyli bir yoğunlaşmadan ve 70'den büyük ise çok yüksek düzeyde yoğunlaşmadan bahsedilir (TÜİK Haber Bülteni, 2010:2).

Yoğunlaşma oranı, kısmi yoğunlaşma ölçüsüyken; Hirschman-Herfindahl ve Rosenbluth indeksleri kapsamlı yoğunlaşma ölçüleridir (Davut, 2002: 225). Herfindahl-Hirchman İndeksi (HH), Hirschman'ın 1945'deki çalışması ve ondan bağımsız olarak Herfindahl'ın 1950'deki çalışmasıyla ortaya koyulmuş bir indekstir. 1980 yılından itibaren yoğun olarak kullanılan HH indeksi, endüstrideki tüm firmaların piyasa paylarının karelerinin toplamından oluşmaktadır ve endüstrideki bütün firmalar dikkate alınarak hesaplanmaktadır:

$\mathrm{HH}=\sum_{\mathrm{i}=1}^{\mathrm{n}} \mathrm{S}_{\mathrm{i}}^{2}$

HH indeksinde, piyasa payı büyük olan firmalara küçük olanlara göre daha fazla ağırlık verilmektedir. Bu indeks 1000 ile 10000 arasında değerler almaktadır. İndeks değeri 1800 ile 10000 arasında ise yüksek piyasa yoğunlaşmasından (düşük rekabetten), 1000 ile 1800 arasında bir değer alıyor ise orta düzey yoğunlaşma düzeyinden (orta düzey rekabetten) ve 0 ile 1000 arasında bir değer alıyor ise piyasada düşük yoğunlaşma düzeyinden (yüksek rekabetten) bahsedilmektedir (Kalkan, www.rekabet.gov.tr, 26.03.2006).

Rosenbluth (1961) tarafindan önerilen ve daha sonra Hall ve Tideman (1967) tarafindan düzenlenen Rosenbluth indeksinde $(\mathrm{RI})^{2}$ ise firmaların endüstrideki payları, büyüklük sıralaması içindeki yerleri ile ölçeklendirilmektedir ve aşağıdaki gibi gösterilmektedir:

\footnotetext{
${ }^{2} \mathrm{RI}$ indeksi, 0 ile 1 arasında değerler alır. Değer 1'e yaklaştıkça piyasa tekel durumuna yaklaşır.
} 
$\mathrm{RI}=\frac{1}{\left(2 \sum_{\mathrm{i}=1}^{\mathrm{n}} \mathrm{iS}_{\mathrm{i}}\right)-1}$

Bir başka yoğunlaşma ölçüsü, Horvath’ın kapsamlı yoğunlaşma indeksidir (CCI) (Horvath, 1970):

$\mathrm{CCI}=\mathrm{S}_{1}+\sum_{i=2}^{n} \mathrm{~S}_{\mathrm{i}}^{2}\left(2-\mathrm{S}_{i}\right)$

$\mathrm{Bu}$ indek, $S_{1}$ endüstrideki en büyük firmanın piyasa payı ile diğer firmaların piyasa paylarının ağırlıklı toplamını gösterir. CCI 'nın, kısmi ve kapsamlı yoğunlaşma ölçülerini birlikte kullanan bir indeks olduğu görülmektedir ve en üst sınır değeri bire eşittir (Tirole, 1988: 222). Yoğunlaşma hesaplamak için kullanılan bir başka ölçüm ise, Entropi katsayısıdır (E). Entropi indeksi, firmaların piyasa paylarındaki eşitsizlikleri, firma sayılarını ve büyüklüklerini dikkate alan bir ölçüttür. Entropi katsayısı, ters yoğunluk ölçümü olup E’nin düşük değerlerinde endüstrideki yoğunlaşmanın daha büyük olduğunu göstermektedir. Entropi katsayısı, Herfindahl indeksi gibi piyasada faaliyet gösteren küçük ve büyük bütün firmaları kapsamına almaktadır ayrıca logaritmik değerleri kullandığından Herfindahl indeksine göre hassas ölçmede daha etkindir (Hexter ve Snow, 1970: 240). Entropi indeksi aşağıdaki şekilde gösterilir:

$E=\sum_{i=1}^{n} S_{i} \log \left(1 / S_{i}\right)$

HH, RI ve CCI karşılaştırıldığında, aralarındaki temel farklılığın, firmaların piyasa payına verilen ağırlıklarla ilgili olduğu görülmektedir. HH indeksinde küçük firmaların ağırlığı az, RI indeksinde ise daha fazladır. Logaritmik değerlerle hesaplanan Entropi katsayısı HH yoğunlaşma indeksine göre firmaların görece büyüklüklerine daha duyarlı olmasından dolayı ön plana çıkmaktadır ( $\mathrm{Su}, 2003$; 15). Ölçütlendirme yöntemindeki bu farklılık nedeniyle, küçük firmaların piyasa paylarındaki değişmeler de indekslere farklı şekilde yansıyacaktır. 


\section{K. ÖNDER.}

Yoğunlaşmanın ölçülmesinde mutlak ve göreli ölçülerden hangisinin daha uygun olduğu hususu tartışma konusu olmuştur. $\mathrm{Bu}$ tartışmada, mutlak ve göreli yoğunlaşma kavramlarından hangisinin daha uygun olduğu konusu önem taşımaktadır. Firma sayısının önem taşıdığını iddia edenler, yoğunlaşma oranı gibi ölçülerin üstünlügünü savunmaktadırlar. Firmaların büyüklük dağılımındaki eşitsizliğin önem taşıdığını öne sürenler ise, göreli yoğunlaşma ölçülerini savunmaktadırlar (Utton, 1970: 49). Needman (1978: 128-29)'a göre yoğunlaşma indeksleri arasında firmaların piyasa paylarını ağırlıklandırma yöntemi açısından farklılıklar vardır. $\mathrm{Bu}$ nedenle, yoğunlaşma indeksleri, firmaların karar alırken rakiplerin sayısı ve büyüklük dağılımına verdikleri ağırlığı farklı şekilde yansıtırlar. $\mathrm{Bu}$ nedenle çalışma da, farklı yoğunlaşma indeksleri kullanılarak endüstrinin yoğunlaşma düzeyi hesaplanmıştır.

\section{ARAŞTIRMANIN KAPSAMI VE AMPİRIKK ÇALIŞMA SONUÇLARI}

\subsection{Araştırmanın Kapsamı}

Araştırma konusunu oluşturan bisküvi, çikolatalı ve şekerli mamuller üretimi Kalkınma Bakanlığı sektör sınıflandırmasına göre, tek sektör çatısı altında yer almamaktadır. Bisküvi üretimi, imalat sanayii gıda sektörü içinde un ve unlu mamuller alt ayrımında yer alırken; helva, lokum, çiklet, şekerleme, çikolata ve çikolatalı mamuller gibi diğer ürünler ise Kalkınma Bakanlığ 1 sektör sınıflandırması içinde gıda sektörü, şeker ve şekerli mamuller sanayii alt ayrımında yer almaktadır. Bu nedenle, çalışmada yer alan araştırma konusu ürünlere ilişkin ISIC Rev.3 sınıflaması temel alınmıştır. Ayrıca bisküvi, çikolatalı ve şekerli mamuller sektöründe yer alan firmaların ürettikleri ürünlerin büyük oranda iç içe geçmeleri, firmaların kar amacıyla mal farklılaştırmalarına gitmeleri ve sektördeki ürünlerin ikamesi yüksek ürünler olmaları nedeniyle her bir ürünün üretim miktarının ve buna bağlı olarak satış değerlerinin raporlanmasında zorluklar yaşanmaktadır. Dolayısıyla, çalışmada; İstanbul Sanayi Odası (İSO) tarafından her yıl belirlenen Türkiye'nin birinci ve ikinci en büyük 500 sanayi firmasının arasında yer alan ve bisküvi, çikolatalı ve şekerlemeli mamuller piyasasında faaliyet 
Dokuz Eylül Üniversitesi Iktisadi ve İdari Bilimler Fakültesi Dergisi Cilt:31, Sayl:2, Yll:2016, ss. 179-208

gösteren firmaların 1997-2014 yılları arasındaki net satış rakamları kullanılarak, bisküvi (gofret) ve çikolatalı ve şekerli mamuller sektörü bir bütün olarak incelenmiştir.

İSO'nun (www.iso.org.tr, 2015) web sayfasından ve yazışma ile İSO'dan temin edilen, birinci ve ikinci en büyük 500 firma verileri içerisinden sektöre ait firmalar, Avrupa Topluluğu Ekonomik Faaliyetlerin İstatistiki Sınıflaması (NACE Rev.2)'nın 10 nolu (Gıda Ürünlerinin İmalatı) koduna ve Birleşik Milletler Tüm Ekonomik Faaliyetlerin Uluslararası Standart Sanayi Sınıflaması (ISIC Rev.2)'nın 311 nolu (Gıda Maddeleri Sanayi) koduna sahip firmalardan derlenmiştir. Sektöre ait piyasa yoğunlaşma değerleri hesaplanırken her firmanın net satış değerleri dikkate alınmıştır (Taymaz, rekabet.gov.tr, 115; İzgi, 2011; Pehlivanoğlu ve Tekçe, 2013: 373).

\subsection{Ampirik Çalışma Sonuçları}

Sektörde faaliyet gösteren firmaların yoğunlaşma dereceleri Yoğunlaşma Oranı, $\mathrm{HH}$, Entropi ve RI indeksleri ile hesaplanmıștır. Yapılan analiz sonucu elde edilen değerler Tablo 7'de verilmiştir.

Tablo 7. Türkiye'de Bisküvi, Çikolatalı ve Şekerli Mamuller Sektöründe Yoğunlaşma Oranları

\begin{tabular}{|c|c|c|c|c|c|c|c|}
\hline Yıllar & $\begin{array}{c}\text { Firma } \\
\text { Sayıs }\end{array}$ & CR-4 & CR-8 & $\begin{array}{c}\text { HH } \\
\text { Indeksi }\end{array}$ & $\begin{array}{c}\text { Entropi } \\
\text { Indeksi }\end{array}$ & RI & CCI \\
\hline 1997 & 13 & 0,76 & 0,91 & 0,180 & 0,879 & 0,171 & 0,463 \\
\hline 1998 & 15 & 0,76 & 0,89 & 0,188 & 0,887 & 0,166 & 0,474 \\
\hline 1999 & 14 & 0,77 & 0,92 & 0,202 & 0,854 & 0,181 & 0,494 \\
\hline 2000 & 9 & 0,80 & 0,98 & 0,211 & 0,787 & 0,175 & 0,507 \\
\hline 2001 & 9 & 0,76 & 0,97 & 0,201 & 0,808 & 0,166 & 0,494 \\
\hline 2002 & 7 & 0,83 & -- & 0,253 & 0,707 & 0,199 & 0,556 \\
\hline 2003 & 9 & 0,74 & 0,97 & 0,173 & 0,845 & 0,154 & 0,452 \\
\hline 2004 & 9 & 0,73 & 0,98 & 0,16 & 0,860 & 0,149 & 0,427 \\
\hline 2005 & 10 & 0,72 & 0,96 & 0,158 & 0,875 & 0,147 & 0,428 \\
\hline 2006 & 10 & 0,78 & 0,96 & 0,211 & 0,808 & 0,168 & 0,505 \\
\hline
\end{tabular}




\section{K. ÖNDER.}

\begin{tabular}{|l|l|l|l|l|l|l|l|}
\hline 2007 & 11 & 0,75 & 0,94 & 0,174 & 0,867 & 0,151 & 0,455 \\
\hline 2008 & 12 & 0,73 & 0,94 & 0,166 & 0,893 & 0,144 & 0,440 \\
\hline 2009 & 14 & 0,71 & 0,92 & 0,158 & 0,925 & 0,136 & 0,426 \\
\hline 2010 & 13 & 0,70 & 0,91 & 0,153 & 0,926 & 0,164 & 0,413 \\
\hline 2011 & 12 & 0,69 & 0,92 & 0,144 & 0,93 & 0,152 & 0,397 \\
\hline 2012 & 12 & 0,68 & 0,93 & 0,145 & 0,917 & 0,154 & 0,401 \\
\hline 2013 & 13 & 0,70 & 0,91 & 0,147 & 0,935 & 0,151 & 0,398 \\
\hline 2014 & 14 & 0,70 & 0,90 & 0,148 & 0,940 & 0,149 & 0,400 \\
\hline
\end{tabular}

* İstanbul Sanayi Odası birinci ve ikinci 500 Büyük Sanayi Kuruluşu verilerinden yazar tarafindan hesaplanmıştır.

Tablo 7'de Türkiye bisküvi, çikolatalı ve şekerli mamuller üretiminde en büyük paya sahip dört büyük firmanın CR-4 yoğunlaşma oranı incelendiğinde; Sektörün 1997 yılına ait satış toplamının \%76'sının dört firmada yoğunlaştığı, 2002'de bu oranın \%83'e yükseldiği ve takip eden yıllarda ise oranın giderek azaldığı, 2014 yılında bu oranın \%70 olarak gerçekleştiği görülmektedir. Hesaplanan CR-4 değerleri, Türkiye İstatistik Kurumu (TÜİK)'nun CR-4 kriterleri dikkate alınarak incelenecek olursa, net satışlar bazında hesaplanan CR-4 oranının \%70'in üzerinde olduğu ve sektörde çok yüksek düzeyde bir yoğunlaşmanın gerçekleştiği dolayısıyla piyasanın oligopolist piyasa yapısı özelliğı taşıdığı görülmektedir. Tabloda bulunan CR-8 değerleri incelendiğinde, y1llar itibariyle \%90 seviyesinin üzerinde seyrettiği görülmektedir (2002 y1lı için CR-8 yoğunlaşma oranı sektörde faaliyet gösteren sekiz firmanın bulunmaması nedeniyle hesaplanamamıştır). Bunun anlamı, piyasada N-firma yoğunlaşma analizi kapsamında çok yüksek düzeyde bir yoğunlaşma olduğudur.

HH indeksi baz alınarak yapılan hesaplama sonucu elde edilen değerler incelendiğinde; analize konu olan sektörde 2002 y1lına kadar yüksek piyasa yoğunlaşmasının var olduğu ve piyasadaki rekabet düzeyinin düşük olduğu; 2002 yılından sonra ise (2006 ve 2007 yılları hariç) orta düzey piyasa yoğunlaşmasının mevcut olduğu ve piyasanın orta düzey rekabete sahip olduğu görülmektedir. $\mathrm{HH}$ indeksi gibi piyasada faaliyet gösteren tüm firmaları dikkate alan Entropi indeksi 
değerleri, zamanla artan bir trend göstermektedir. Entropi indeksi değerlerinin artması, yayılma oranının arttığını; bir başka ifade ile entegrasyon düzeyinin yüksek olduğunu ifade etmektedir (Laaser ve Schrader, 2002: 16-18).

RI indeks değerleri incelendiğinde; bu değerin de HH indeksi gibi 2002 y1lına kadar yüksek seyrederken, takip eden yıllarda azaldığı dikkat çekmektedir. Bu durum, 2002 yılına kadar yoğunlaşmanın yüksek olduğunu ancak yoğunluğun 2014 yılına kadar azaldığını ifade etmektedir. CCI indeksi hesaplarına göre, yoğunlama oranlarının dalgalı bir seyir izlediği ve 2006 yılından itibaren azalan oranda azaldığı görülmektedir. Diğer indeksler gibi piyasanın orta düzey bir rekabete sahip olduğunu göstermektedir.

Dünya bisküvi ihracatında dokuzuncu sırada yer alan Türkiye'nin üretim miktarını belirleyen en önemli aktör, yurt dışı tüketimdir (http://www.trademap.org, 10.12.2016). Talebe göre üretimini gerçekleştiren bisküvi, çikolatalı ve şekerlemeli mamuller sektörünün piyasa yapısının monopolcü rekabet ile oligopol arasında yer aldığı görülmektedir.

\section{SONUÇ VE DEĞERLENDİRME}

Çalışmada, İstanbul Sanayi Odası tarafından her yıl belirlenen, Türkiye'nin birinci ve ikinci en büyük 500 sanayi firmasının arasında yer alan ve bisküvi, çikolatalı ve şekerlemeli mamuller piyasasında faaliyet gösteren firmaların 19972014 dönemi net satış verileri kullanılarak sektörün yapısı analiz edilmiştir. Çalışmada kullanılan yöntemlerin kriterleri göz önünde bulundurularak incelendiğinde; Bisküvi, çikolatalı ve şekerli mamuller sektörünün, CR-4 ve CR-8 yoğunlaşma analizlerine göre oligopolist piyasa yapısı özelliğini taşıdığı ancak incelenen dönemin sonlarına doğru monopolcü rekabet yapısına büründüğü, $\mathrm{HH}$ analizine göre ise piyasanın orta düzey yoğunlaşmaya sahip olduğu diğer bir ifade ile oligopol bir yapı içinde olduğu söylenebilir. Sektörde ortaya çıkan piyasa yapısı; sektör ürünleri insan sağlığını yakından ilgilendirdiği için ilgili Bakanlık ve resmi kurum ve kuruluşlardan alınması gereken ruhsat ve izinlerin varlığı, sektör yatırımlarının büyük sermaye gerektirmesi, üretim sürecinde kullanılan temel 


\section{K. ÖNDER.}

girdilerin dünya fiyatlarının üzerinde olması, taşımacılık maliyetlerinin yüksek olması ve üretim sürecinde kullanılan katkı maddelerinde dışa bağımlı olunmasının (yeni firmaların sektöre girişlerinde büyük külfet getirmesinin bir sonucu olarak) piyasaya yeni girişleri engellenmesine bağlanabilir. Ayrıca sektörde bulunan orta ve küçük kapasiteli işletmelerin büyük ve modern teknolojiye sahip işletmelerle teknolojik açıdan rekabet edememeleri de piyasa yapısının oligopol olmasında diğer bir faktördür. $\mathrm{Bu}$ engeller dolayısıyla satılan orta ve küçük kapasiteli işletmeler piyasa içinde bulunan büyük firma grupları tarafından satın alınmakta, bu da piyasa yoğunlaşmasının artmasına ve piyasa yapısının rekabetten uzaklaşarak oligopolist bir yapıya dönüşmesine neden olmaktadır. $\mathrm{Bu}$ durumda yapılması gereken, Rekabet Kurumu ve bu kuruluş gibi ulusal ve uluslararası kurumların, ülke içindeki ve dışındaki tüm piyasaları gözetim altında tutmalarıdır. Bunu yerine getirirken konularında uzman kişilerle ve etkili analiz yöntemleriyle piyasa verileri değerlendirilmeli ve elde edilen sonuçlara göre de üretici veya tüketicilerin zarar görmesini engellemek için caydırıcı yaptırımlar uygulanmalıdır. Yurtiçinde piyasa yapısı üzerinde etkin bir dizi önlem alınırken bu önlemlerin sektör ihracatçısı firmaların yurtdışı pazar payını olumsuz yönde etkileyecek kararlar olmamasına dikkat edilmelidir. Ayrıca sadece ülke içerisinde Kobilere yönelik korumacı bir politika güdülmemeli. Sektörün zayıf yanları güçlendirilmeli, güçlü yanları ise desteklenerek sektör, dünya rekabetinde yer alabilecek konuma taşınmalıdır.

\section{KAYNAKÇA}

AKAL, M. (2008), "Ortadoğu Sinır Ülkeleriyle Dış Ticaret Yoğunlaşması ve Yapısal Değişim”, Gaziantep Üniversitesi Sosyal Bilimler Dergisi, 7(2):271-296.

AKTAŞ, E., YURDAKUL, O. (2001), "The Analiysis of Flour Mill Industry in Turkey”, Munich Personal RePec Archive, 1-15.

Ankara Ticaret Borsas1 (2008), Bisküvi Sektörü Raporu, http://www.ankaratb.org.tr/lib_upload $/ 52$ _Bisk $\% \mathrm{C} 3 \% \mathrm{BCvi} \% 20 \mathrm{Sekt} \% \mathrm{C} 3 \% \mathrm{~B} 6 \mathrm{r} \% \mathrm{C}$ 3\%BC\%20Raporu_30_06_2008.pdf, (10.12.2015). 
BAILEY, D., BOYLE, S.E. (1971), "The Optimal Measure Of Concentration", Journal of the American Statistical Association, 66, 702-706.

BAIN, J. (1968), Industrial Organization, 2.B, John Wiley and Sons, Inc, New York.

ÇERMIKLİ, H. (2014), Endüstriyel İktisat, Gazi Kitapevi, Ankara.

ÇİL YAVUZ, N. (2000), “Türkiye'nin Dış Ticaretinin Mallar ve Ülkeler Açısından Konsantrasyon Analizi (1975-1998)”, Çimento İşveren Dergisi, 14(5):3-12.

DAVUT, L. (2002), Sanayi İktisadı Piyasa Yapısı Unsurları, İmaj Yayınevi, Ankara.

DENIZER, C. (1999), "Foreign Entry in Turkey's Banking Sector, 1980-97", World Bank Policy Research Working Paper No. 2462, http://papers.ssrn.com/sol3/Papers.cfm?abstract_id=632532, (27.03.2016).

DEVINE P.J., JONES R.M., LEE N., TYSON W.S. (1974), An Introduction to Industrial Economics, George Allen\&Unwin Ltd., London.

DURUKAN, T., HAMURCU, Ç. (2009), "Mobil İletişimde Pazar Yoğunlaşması", Journal of Black sea Studies", 6(22), 75-86.

DONOWITZ, I., HUBBARD, R. G. ve PETERSEN, B. C. (1987), "Oligopoly Supergames: Some Empirical Evidence on Prices and Margins", The Journal of Industrial Economics, 17, 1-17. 


\section{K. ÖNDER.}

ERLAT, G. (1991), "İhracat ve Endustriyel Yoğunlaşma Arasındaki İlişkinin İmalat Sanayiinden Seçilmiş Bazı Sektörler Açısından İncelenmesi", http://arsiv.mmo.org.tr/pdf/10687.pdf, (31.03.2016).

GÜNALP, B. (2002), "Yarışabilir Piyasalar Yaklaşımı ve Rekabet Piyasaları", Gazi Üniversitesi İ̇BF Dergisi, 4(3), 49-66.

HALL, M., TIDEMAN, N. (1967), "Measures of Concentration", Journal of The American Statistical Association, 62, 162-168.

HANNAH, L., KAY, J. (1977), Concentration In Modern Industry, London, Mac Millan.

HATIRLI, S.A. (2014), Mikro İktisat, Alter Yayıncılık, Ankara.

HEXTER, J.L., SNOW, J.W. (1970), “An Entropy Measure of Relative Aggregate Concentration", Southern Economic Association, 36(3), 239-243.

HORVATH, J. (1970), "Suggestion For A Comprehensive Measure of Concentration", Southern Economic Journal, 36, 446-452.

İstanbul Sanayi Odas1, Türkiye'nin 500 Büyük Sanayi Kuruluşu (1997-2014), http://www.iso.org.tr/projeler/turkiyenin-500-buyuk-sanayi-kurulusu/., (11.10.2015).

İstanbul Ticaret Odası, Bisküvi-Şekerleme Sektör Profili, http://www.ito.org.tr/itoyayin/0004524.pdf, (31.03.2016).

İZGİ, B.B. (2011), "Devlet Yardımları, Sektörel Yoğunlaşma ve Rekabet", Mevzuat Dergisi, 14 (159), http://mevzuatdergisi.com/2011/03a/01.htm, (27.03.2016). 
KALKAN, E. (2004), "Yatay Birleşmelerin İncelenmesinde İktisadi Tekniklerin Kullanılması", Rekabet Kurumu Uzmanlı Tezi, Ankara, http://www.rekabet.gov.tr/File/?path=ROOT\%2F1\%2FDocuments\%2FUzmanl\%2 5c4\%25b1k\%2BTezi\%2Ftez64.pdf , (26.03.2016).

KAYNAK, S., ARI, Y.O. (2011), “Türk Otomotiv Sektöründe Yoğunlaşma: Binek ve Hafif Ticari Araçlar Üzerine Bir Uygulama”, Ekonomik Yaklaşım, 22(80), 3958 .

KÜÇÜKKİREMITTÇI, O., KARACA, M.E. ve EŞIYOK,B.A. (2010), “Türkiye'nin İhracatında Öne Çıkan Sektörlerde Temel Pazarlar, Rakipler ve Rekabet Gücü". Türkiye Kalkınma Bankası Ekonomik ve Sosyal Araştırmalar Müdürlüğü, Ankara.

KOCH, J.V. (1980), Industrial Organization and Prices, 2. B, Englewood Cliffs, N.J. Prentice Hall, Inc.

KÖSEKAHYAOĞLU, L. (2007), "Türkiye Dış Ticaretinde Ürün ve Ülke Bazında Yoğunlaşma: 1980-2005 Dönemi Üzerine Karşılaştırmalı Bir Analiz”, İstanbul Üniversitesi Siyasal Bilgiler Fakültesi Dergisi, 36, 15-34.

LAASER, C.F., SCHRADER, K. (2002), European Integration and Changing Trade Patterns: The Case of the Baltic States, Kiel Institute of World Economics, Kiel Working Paper No. 1088.

LOW, R.E. (1970), Modern Economic Organization, Homewood Illinois, Richard D.Irwin, Inc.

MARFELS, C. (1975), "A Bird's Eye View To Measures of Consentration”, Antitrust Bulletin, Sonbahar, 485-563.

MULLER, J. (1976), "The Impact of Mergers On Concentration: A Study Of Eleven West German Industries", Journal of Industrial Economics, 25, 113-132. 


\section{K. ÖNDER.}

NEEDMAN, D. (1978), The Economics Of Industrial Structure Conduct and Performance, Holt, Rinehart and Winston.

NOLAN, E., SANTOS, P., SHI, G. (2012), "Market Concentration And Productivity in the United States Corn Sector: 2002-2009", Selected Paper prepared for presentation at the Agricultural \& Applied Economics Association 2012 Annual Meeting, Seattle WA, 12-14.

ONDOĞAN, E.N. (2008), "Gençlerin Çikolata Tüketiminde Tercihleri Üzerine Bir Alan Araştırması", e-Journal of New World Sciences Academy, 3(1):158-170.

ÖZEL, Ö. (2006), İstanbul İlinde Çikolata Sektöründe Tüketici Eğilimleri ve Markalar Arası Rekabet Gücü, Yayımlanmamış Yüksek Lisans Tezi, Trakya Üniversitesi Fen Bilimleri Enstitüsü, Edirne.

PEHLIVANOĞLU, F., TEKÇE, E. (2013), “Türkiye Elektrik Enerjisi Piyasasında Herfindahl- Hirschman ve CRm Endeksleri İle Yoğunlaşma Analizi”, Abant İzzet Baysal Üniversitesi Sosyal Bilimler Dergisi, 13(2), 363-385.

PICKERING, J.F. (1974), Industrial Structure And Market Conduct, Martin Robertson ve Co. Ltd.

POLAT, Ç. (2007), "Yoğunlaşma ve Piyasa Yapısı İlişkisi Çerçevesinde Türk Çimento Sektörünün Yapısal Analizi”, Anadolu Üniversitesi Sosyal Bilimler Dergisi, 7(2), 97-115.

SHY, O. (1995), Industrial Organization: Theory and Applications, MIT Press, New York.

SERTAKAN, S.G. (2006), Bisküvi ve Kraker Üretiminde Tritikale Ununun Kullanım Olanakları, Trakya Üniversitesi Fen Bilimleri Enstitüsü, Gıda Mühendisliği Ana Bilim Dalı, Yayımlanmamış Doktora Tezi, Edirne. 
SU, K. T. (2003), Rekabet Hukukunda Teşebbüslerin Hakim Durumunun Belirlenmesinde Pazar Gücünün Ölçülmesi, Rekabet Kurumu (Yayın No: 0094), Ankara.

SUNG, N. (2014), "Market Consentration and Competition in OECD Mobile Telecominications Markets", Applied Economics, 46(25), 3037-3048.

TARU, V.B., LAWAL, H. (2011), "Corcertration in the North Eastern Nigeria's Yam Market: A Gini Coefficient Analysis", Journal of Tropical Ariculture, Food, Environment and Extension, 10(2), 49-57.

TAYMAZ, E. "Teknolojik Gelişme ve Piyasa Yapısı İmalat Sanayii Üzerine Bir İnceleme", $\quad$ Perşembe Konferansları, http://www.rekabet.gov.tr/File/?path=ROOT\%2F1\%2FDocuments\%2FPer\%25c5 $\% 259$ fembe $\% 2$ BKonferans $\% 25 \mathrm{c} 4 \% 25 \mathrm{~b} 1 \% 2 \mathrm{BYay} \% 25 \mathrm{c} 4 \% 25 \mathrm{~b} 1 \mathrm{n} \% 2 \mathrm{Fperskonfyyn}$ 72.pdf, (26.03.2016).

TIROLE, J. (1988), The Theory of Industrial Organization, The MIT Press, Cambridge, London.

Türkiye Cumhuriyeti Ekonomi Bakanlığı (2013), Bisküvi, Sektör Raporları, İhracat Genel Müdürlüğü Tarım Ürünleri Daire Başkanlığı, https://www.ekonomi.gov.tr/portal/content/conn/UCM/uuid/dDocName:EK051165, (10.12.2015).

Türkiye Cumhuriyeti Ekonomi Bakanlığı (2013), Şekerli ve Çikolatalı Mamuller, Sektör Raporları, İhracat Genel Müdürlüğü Tarım Ürünleri Daire Başkanlığı, https://www.ekonomi.gov.tr/portal/content/conn/UCM/uuid/dDocName:EK051171, (22.12.2015).

Türkiye İstatistik Kurumu, Sanayi Ürünleri Yıllık Üretim ve Satış İstatistikleri 2005 - 2013, http://www.tuik.gov.tr/PreTablo.do?alt_id=1066, (09.01.2016).

Türkiye İstatistik Kurumu, Haber Bülteni 2010, http://www.tuik.gov.tr/PreTablo.do?alt_id=1036\#, (26.03.2016). 


\section{K. ÖNDER.}

Türkiye Kalkınma Bankası A.Ş. (1999), Bisküvi-Gofret ve Şekerli Mamuller, Sektörel Araştırmalar SA/99-6-12, http://www.kalkinma.com.tr/data/file/raporlar/ESA/SA/1999-SA/SA-99-06-

12_Biskuvi_ve_Sekerli_Mamulleri_Sektoru.pdf, (26.03.2016).

TradeMap, http://www.trademap.org/Country_SelProductCountry_TS.aspx, (22.12.2015 ve 10.01.2016).

UTTON, M.A. (1970), Industrial Concentration, Middlesex, England, Penguin Books.

ÜNAL, S., DENIZ, A., CAN, P. (2008), "Marka Bağlılı̆g1 ve Kişisel Değerler Açısından Pazar Bölümleme", Atatürk Üniversitesi İktisadi ve İdari Bilimler Dergisi, 22(1): 211-237. 